\title{
How Was the Power of the Criminal Corpse Harnessed in Early Modern England?
}

\section{The Context}

The transition from medieval to early modern, though by no means clear cut, is a useful heuristic because of the deep intellectual and social changes that unfolded over the period of the Reformation and Renaissance. Dyer has noted that many of the processes traditionally identified with the Early Modern Period in fact have much earlier origins, and in this contention he fits into an established tradition of finding medieval origins of the modern world. ${ }^{1}$ However, in the history of death in Britain (though perhaps not so much in the history of punishment), a sixteenth-century transition from medieval to modern, in which the Reformation plays a significant part, is a defensible division. The doctrinal and liturgical changes of the Protestant Reformation had profound effects on the way people prepared for death, and on the relationship between the living and the dead.

\section{Changes in Criminal Justice During the Age of Spectacular Punishment}

During the sixteenth century, the development of a modern, scientific approach to the body intersected with an increasingly formalised, wide-ranging and state-run approach to the law, to institutionalise post-mortem anatomical dissection as a treatment for the criminal corpse.

(c) The Author(s) 2018

S. Tarlow and E. Battell Lowman, Harnessing the Power of the Criminal Corpse, Palgrave Historical Studies in the Criminal Corpse and its Afterlife, https://doi.org/10.1007/978-3-319-77908-9_3 
In 1540, Henry VIII founded by charter the Company of Barber Surgeons, giving professional legitimacy and formal recognition to what had not always been an entirely respectable trade. ${ }^{2}$ The same charter included provision for the bodies of four executed felons per annum to be made available to the Company, for anatomical dissection. In 1565 the Royal College of Physicians started giving anatomical lectures, which continued to be a college fixture until the building's destruction in the Great Fire of 1666. Also in 1565, John Caius obtained an annual grant of two bodies to be delivered to Gonville College, Cambridge, and in 1626 Charles I allowed the Reader in Anatomy at Oxford to claim the bodies of anyone executed within 21 miles of the city. ${ }^{3}$ Because it was important that the bodies for dissection were as fresh as possible, surgeons liaised directly with the sheriff, whose job it was to see that sentences were carried out.

However, by the 1690s the Barber-Surgeons were finding it harder to claim bodies from the sheriffs. Official supply of executed criminals could not keep pace with demand. By the time of the Murder Act of 1752 only a very few of the subjects of anatomical dissection came through judicial channels and very few ended up in the universities of Oxford and Cambridge, or at the Royal College. The numerous private anatomy schools that sprang up like mushrooms in the early eighteenth century were unscrupulous in their efforts to obtain the necessary specimens for educational dissection.

Punitive dissection was, argues medievalist Katharine Park, a north European practice in origin. ${ }^{4}$ In Italy, she argues, a different cultural tradition in the Late Medieval and Early Modern Periods meant that the body was less closely associated with the person. A dead body had far greater symbolic and emotional impact in northern Europe where folk practices and beliefs suggest that the body, even after death, retained some of the essence and life force of the person (an idea explored later in this chapter). The display of the corpse in Italian justice was an assault on the memory or honour of the executed, not an assault on their personhood, claims Park. ${ }^{5}$ While Park's contrast is perhaps overdrawnit is certainly the case that the display of heads and quarters above city gates, for example, was an attack on the memory and honour of north Europeans, too- the idea of residual personhood does have explanatory force in explaining some traditional medical beliefs and, allied to some wobbly theology, might have been significant in shaping public attitudes to dissection. 
As Sawday observes, penal dissection per se is a creation of the eighteenth century. ${ }^{6}$ In Tudor and Jacobean times, bodies, especially those of traitors, were pulled apart, but this kind of public dismemberment was about avenging an injury to the sovereign, and not primarily about either public recompense or scientific education. Although the bodies of some executed felons were made available (in vanishingly small numbers) for anatomical research, this post-mortem fate was not part of the sentence, nor was there any sense in which the likelihood of meeting the anatomist's scalpel was linked to the depravity of the crime. Hanging in chains, however, in contrast to dissection, does appear frequently as an explicit part of sentencing before the Murder Act (in fact, gibbetings were more frequent in the decades immediately preceding the legal formalisation of the punishment than in the years following it, as we will see in Chapter 6). Hanging in chains, moreover, was particularly linked to certain kinds of serious crime. These were often murders or aggravated serious property crimes, such as highway robbery, robbery of the mail or smuggling, especially when another person was killed or seriously hurt. The gibbet also related strongly to the location of the crime, and was a punishment that was given particular force by being staged at the place where the crime was committed. In this, hanging in chains was similar to, and indeed often followed directly from, hanging at the scene of crime, a practice which was widely practised up to the eighteenth century, especially in parts of southern England, but was becoming unusual by the early nineteenth century. ${ }^{7}$

\section{The Uses of the Dead in Early Modernity}

What can you make from a dead body? The answers are numerous, both literal and metaphorical, and the criminal corpse was used deliberately in all these kinds of creations. You can use the dead criminal body to build scientific knowledge. Through methodical exploration of the body's interior, the basic principles of scientific biology, medicine and surgery (as opposed to a medicine built on the authoritative statements of classical authors) were discovered. The Early Modern Period was key in the history of anatomy, and the methodical and objective study of actual bodies, rather than texts, was essential in this process.

You can use the actual material substance of the body to make medicine for the living: From skull powder to 'mummy' made from the desiccated flesh of ancient bodies - or the rapidly dried meat of more recent 
ones; from drinking fresh blood to curing tumours with the touch of a hanged man's hand, the vital force that persisted in a fit, young body after life had been suddenly extinguished could be captured and channelled into the failing bodies of those still alive. ${ }^{8}$ With a dead body you can make magic. In early modernity the distinction between science, medicine and magic was not always clear or relevant. How should we categorise the widespread practice of carrying teeth extracted from the skulls of the dead, as a safeguard against toothache, for example? In other cases, such as the spell apparently used successfully by John Dee to raise a man from the dead and make him act as Dee's personal servant, we would have no difficulty in seeing the dead body as a place of magic. ${ }^{9}$

Less literally, one can use a dead body-and especially a dead criminal body - to make a point or a statement. The spectacle of bodily punishment and of post-execution sanctions upon the body, its particular memorability, made the executed criminal body in early modernity an exceptionally potent symbolic resource in the construction of political power. A dead body can be used to make stories, or even to make history. By elaborating, venerating, desecrating or reshaping a body, it can be made into a saint or a villain according to the tales told about it. Whole or in pieces, the dead body provides the raw material that the storyteller, historian, politician or poet reconfigures to make a particular kind of truth.

All these uses for a dead criminal body had occurred in medieval England, but during early modernity they were more extensively discussed and formalised. The role of law in determining the treatment of an executed body was stronger and more consistent; the practice of scientific anatomy more methodically set out; and the curative powers of corpse medicine classified and codified in surgeons' and apothecaries' compendia and vade mecums (handbooks).

This chapter surveys the uses of the criminal corpse from the mid-sixteenth to the mid-eighteenth century. While the body during this period was not as extensively controlled by the State as it would be during the period of the Murder Act, it was nevertheless at this time that most of the legally determined treatments of the criminal corpse-hanging in chains, or dissection as punishment, for example-entered into customary use. Our approach to the criminal body in this chapter, and indeed in the book as a whole, is to view it as a powerful resource which could be deployed strategically to rhetorical or practical effect. 


\section{Changing Meanings of the Dead Body}

\section{Building a New Medicine}

The sixteenth, seventeenth, and eighteenth centuries were periods of rapid progress in the exploration of the body and developing scientific understanding of anatomical systems and processes. The centuries between the European Renaissance and the age of the Murder Act were a period of transformation in how the human body was viewed, from a collection of humours to an integrated machine. ${ }^{10}$ Over the same period, the dominant way of knowing and understanding the body also shifted: this time from a knowledge gained from books to one that accorded greater significance to first-hand observation and experiment. Knowledge of the world, gained from the new scientific principles, was also over this period transformed from being a way to know God, to being a way to change the world. To assert human mastery over nature one had to know it deeply, and with that knowledge came the ability to shape and control it. That power included the human ability to transform materials and substances, to change the shape and productivity of the land by mapping, enclosing, taming and improving it, and of other animals. It also included the ability to intervene in the workings and faults of the human body. That the body, once the soul had gone, was a part of Nature was increasingly taken for granted in the period. Harris, Robb and Tarlow describe the process by which new philosophy and theology converged on a new kind of mind/body split that 'provided a whole new way of looking at the world, a new kind of gaze'. ${ }^{11}$ This new way of looking-investigative, empirical, neutral—was science, and it became the dominant approach to the human body.

The human body, like the universe of which it was a part, followed the rules and obeyed the mechanisms created by God. A new consensus developed in the early modern period about what knowledge was. The world could be better known through direct observation than through the writings of authorities, a position that mirrored the Protestant belief that the human relationship with God should be direct and mediated only by prayer and the Bible, not through the intermediaries of priests and teachers. Where possible, practical knowledge and experiment should form the basis of understanding, as opposed to medieval knowledge which paralleled practical experience of the world 
with an authoritative written discourse sanctioned by ancient authority and within which contradiction was not a problem. C.S. Lewis pointed out in his review of medieval bestiaries that the authority of literature was not only important in describing exotic animals such as giraffes and elephants, but also provided 'facts' about familiar domestic animals that must surely have been at odds with people's daily experience, such as the assertion that horses shed tears at the death of their master, or that the adder protected itself from snake charmers by curling up with one ear against the ground and the other stopped up with the tip of its tail. ${ }^{12}$ Similarly the idea was advanced that beavers could cast off their genitals to distract predators while they escaped, hence its Latin name, castor. ${ }^{13}$

The new medicine involved a paradigm shift from respecting the word of authorities to learning directly from dissected cadavers. This transformation is generally located in sixteenth-century Europe and is attributed to Vesalius. ${ }^{14}$ It was assisted by a general opening up of attitudes towards intellectual discovery and the eventual acceptance by Pope Clement VII of the practice of human dissection for anatomical purposes. ${ }^{15}$

In the case of the human body, the dominant medieval medical approach had seen disease as the result of an imbalance of humours, the four essential life fluids, following the teachings of Galen. ${ }^{16}$ This humoral theory also made character inseparable from health. The empirical gaze of the new medical science replaced the sack of competing fluids with a balanced mechanism that needed to be observed. Overlapping both the humoral model and the machine, there was a period in the seventeenth century where one of the widespread metaphors of body was the microcosm-the body as geography whose uncharted waters and mysterious territories needed to be explored and mapped. ${ }^{17}$ The consequent privileging of a rational, masculine, knowing subject, valorised as pioneer, explorer or hero-is at the heart of recent attacks on Enlightenment thought. ${ }^{18}$

Being a doctor or surgeon went from a trade to a profession and by the eighteenth century was a respectable life for a gentleman. Medical knowledge was collective and incremental, accumulating in books and periodicals, communicated through formal, college-based curricula, lectures and demonstrations.

The detailed mapping of the human body was fundamental to the project of understanding its internal relationships and mechanisms. A cartographic metaphor of exploration and geography was widely used to describe this undertaking. ${ }^{19}$ As a metaphor of anatomy, the voyage 
of discovery sat equally well with a microcosmic view of the body, still important during the sixteenth and seventeenth centuries. It was also an attractive analogy for the new science because it conveyed the importance of actually visiting - seeing for oneself-the workings of the body. Etymologically, of course, the autopsy was a 'seeing for oneself' of the body's interior.

Revealing the complexity of the body's hidden and secret places was not, until the eighteenth century, fully divorced from a theological or philosophical consideration of the body. The introduction to Anthony Nixon's 1612 book of anatomy (significantly entitled The Dignity of Man, Both in the Perfections of His Soule and Bodie) answers the question, 'What commoditie cometh by anatomy of the body?' with the point that 'It puts us in minde of our mortality, and teacheth us that if the providence of God be so wonderful in the composition of the vilest and the earthly partes, It must needs follow that it is farre more great, and admirable in the creation of the Noble parts, especially of the Soule' ${ }^{20}$ Until the beginning of the eighteenth century, the introductions to most anatomical textbooks presented the detailed study of anatomy as a way of better knowing the self ('nosce te ipsum' being a recurrent motif in illustrations and frontispieces and thus of knowing God - Fig. 3.1). ${ }^{21}$

Of course, in order to admire the infinite subtlety and beauty of the mind of the Creator, direct, physical experience of the body's interior was essential. A supply of passive objects for the probing eye and scalpel of the anatomist had to be secured. Although only a comparatively small number of people in early modern England had direct and personal experience of anatomical dissection, the idea of anatomy and dissection was a potent cultural metaphor, explored further in Chapter 8 .

\section{The Dissected Body as Cultural Symbol}

The anatomical dissection of the criminal body provided the structuring metaphor for numerous cultural phenomena in the early modern period. The separation, enumeration and description of body parts is evident in, as Hillman and Mazzio note, 'pictorial isolation, poetic emblazoning, mythic spargamos, satirical biting, scientific categorising, or medical anatomizing'. ${ }^{22}$ Numerous early modern texts directed towards the exploration and rational examination of a topic called themselves 'anatomies'. ${ }^{23}$ The metaphorical use of 'anatomy' for any analytical examination continued into the eighteenth century. 


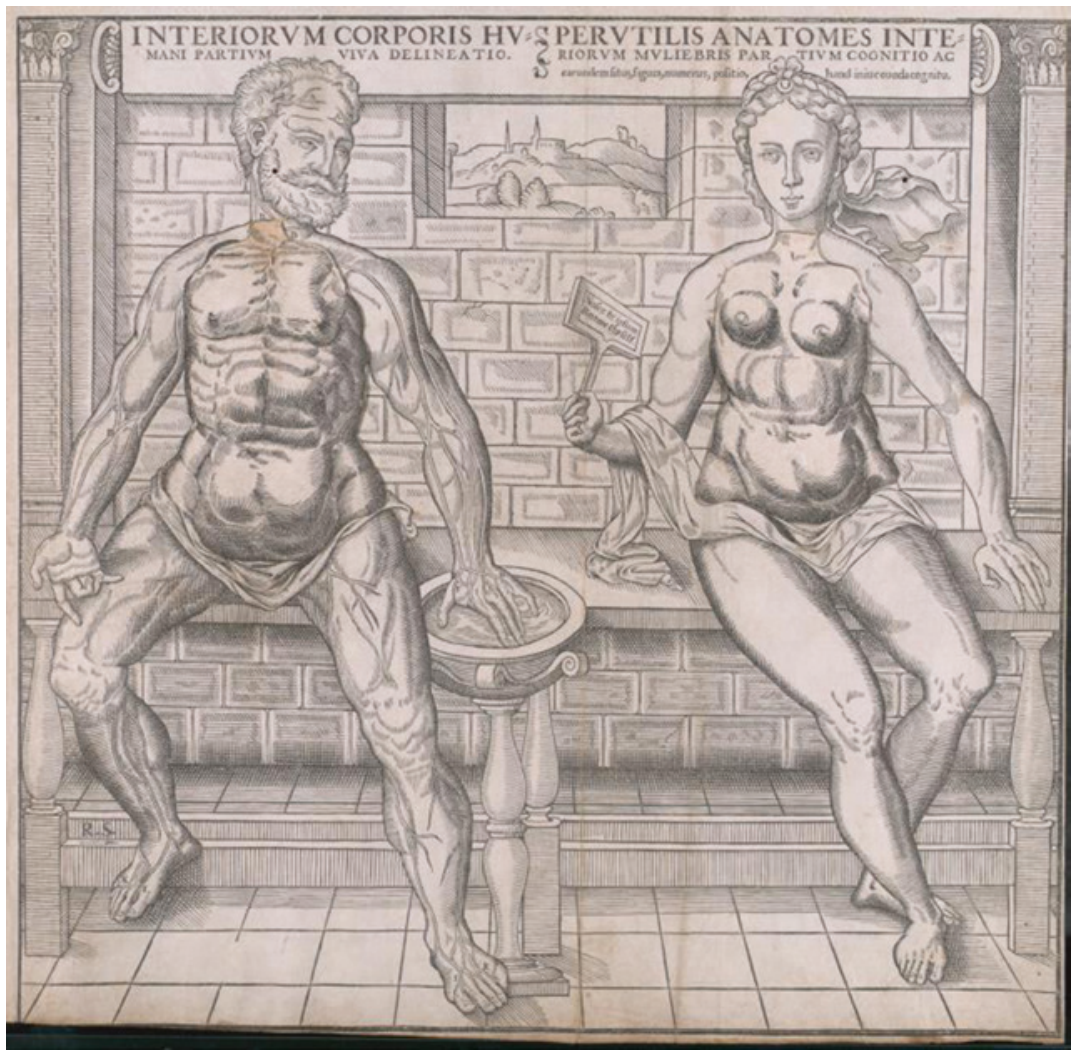

Fig. 3.1 Woodcut by R.S. Interiorvm corporis hvmani partivm viva delineatio (The Thomas Fisher Rare Book Library, University of Toronto)

\section{Medicine and Folklove}

In today's world, there is a wide choice of possible treatments for arthritis. We have little difficulty in categorising most of these as belonging to either orthodox, scientific medicine or alternative, folkloric practices. A doctor who has trained in medicine in most of the world might recommend a course of steroid injections or refer you for surgery, but is unlikely to suggest you carry a potato in your pocket. In the seventeenth century the separation between folk and orthodox medicine was less clearly established, and in many ways the period was one during which 
modern medicine tried to cut free from superstition and unsubstantiated beliefs based on now discredited models of health and disease. The survival of numerous folkloric remedies into the nineteenth century and beyond, when many of them were collected by county folklorists, seems to have been particularly evident among poor and rural people, who were presumably unable to afford trained, professional medical care.

\section{The Social Consequences of Deviancy}

The body of the executed criminal was capable of bearing a significant symbolic weight. Take, for example, the case of Guy Fawkes, an executed criminal whose proxy body still anchors a calendar festival that rehearses the social consequences of deviancy. As every British schoolchild knows, Guy Fawkes was one of the instigators of a Catholic plot to blow up parliament during its official opening, when James I would have been present, on 5 November 1605. The plot was discovered and Fawkes was found with 20 barrels of gunpowder in a cellar beneath the Houses of Parliament. Apparently spontaneous celebrations for the preservation of the king began that very year, with bonfires being built around London. An Act of parliament then ordered that the anniversary of the foiled plot should be celebrated annually as a day of thanksgiving for the king's life. In the next few years the practice of celebrating the anniversary of the occasion with bonfires spread around the country. Effigies of Guy Fawkes, and sometimes also the Pope, were customarily placed on the bonfire. Today, 'bonfire night' or 'Guy Fawkes day' is known and celebrated in most of Great Britain and in some colonial/post-colonial countries too. Burning the guy is the central and indispensable part of bonfire night tradition. Insider/outsider status is clearly enacted upon the body (or its proxy) in a way that not only expresses but also constructs social expectations.

The easy slippage between body and effigy was not unusual in early modern England, as we will see in the case of Oliver Cromwell, for example. ${ }^{24}$ The body of Guy Fawkes, or rather a resurrected and recreated simulacrum or pastiche of his body, became the object of a ritual designed to reflect and create standards of political, religious and social conformity. However, in the twenty-first century, the executed traitor Guy Fawkes was again resurrected and transformed to do duty as a force of resistance and critique to government. ${ }^{25}$ 


\section{The Reformation and the End of Purgatory}

There is little consensus among historians of England about the nature and extent of change consequent upon the Protestant Reformation of the mid-sixteenth century. The redistribution of former Church property undoubtedly reshaped the political and economic as well as the geographical landscape. Max Weber's argument that a distinctively Protestant way of thinking permitted or even promoted the individualistic capitalism of modernity has been widely influential. ${ }^{26}$ Protestantism does appear to be associated with the key social, aesthetic and philosophical viewpoints of the seventeenth and eighteenth centuries, although whether religious doctrine followed, informed or developed alongside broader attitudinal change is debatable. One area, however, in which religious reformation undoubtedly did lead to a thoroughgoing change in practice, discourse and feeling is in the relationship between the living and the dead. Although Ariès claims that differences between Catholics and Protestants are insignificant 'on the level of collective psychology', in fact the transformation from late medieval Catholicism to early modern Protestantism profoundly altered the parameters of our relationship with the dead. ${ }^{27}$ It is possible that this change in turn affected the Catholicism of the Counter-Reformation on the continent. But to deny the impact of a new post-mortem geography is to ignore changes in secular as well as devotional practice. In the previous chapter, we considered the significance of Purgatory as an essential conceptual space, in which the living were able to interact with the dead. While the dead waited out their time in Purgatory, expiating their venial sins and preparing for salvation, their friends, relatives, beneficiaries and descendants could help them along with prayers, masses and gifts to the Church. For the living, who were thinking about their own mortality and the probable fate of their souls (and in the late Middle Ages, that meant pretty much everyone), the capacity of this world to have an impact upon the next meant that they could improve their own chances of Heavenly resurrection by endowing Church establishments in exchange for promises of prayers for their souls after death. There was also money to be made by the Catholic Church for selling indulgences, bulls and other 'Get out of Jail Free' tokens.

By getting rid of Purgatory the Protestant reformers utterly transformed the easy reciprocity between living and dead that the medieval economy of prayer and intervention had allowed. At death, a Protestant stood alone before God. Their salvation, the chances of which ranged 
across Protestant sects from fairly good to vanishingly slim, had already been determined, and not a million masses, nor all the indulgences in Europe could make a bit of difference. For the bereaved, this change left them powerless in any spiritual capacity. All that was left to them was to perpetuate the earthly fame of the dead, which they did through a new fluorescence of commemorative monuments, paintings and the emerging genre of memorial and mourning poetry. ${ }^{28}$

At the same time, the folklore of ghosts, monsters, revenants and fairies, always a little incoherent and contradictory, lost an important part of its geography: a place for 'all the disjecta of peripheral human experience'. ${ }^{29}$ Since magical beings could no longer come from the moral Switzerland of Purgatory, it appeared to many that they must therefore come from Hell, and be unambiguously the Devil's cohorts. Periods of intense anxiety about the work of the devil, and associated waves of witch persecution punctuated the two centuries following the Reformation.

Protestants' rejection of the capacity of the living to influence the fate of the soul ironically led to an even greater concentration on the dead body. The bereaved began to channel the time, energy and resources they would formerly have invested in prayers for the soul into elaborate obsequies, enduring memorials and attention to the dead body itself. This was ironic because Protestantism shared with Catholicism a generally disdainful and suspicious attitude towards the body-living or dead. The body, including its functions, urges, and mutability was a temptation to sin and a source of wickedness. The living body must therefore be denied, ignored and opposed as far as possible. William Sherlock, a prominent seventeenth-century Protestant theologian suggests that, since the body was ultimately fated to decay, and bodily drives were temptations to sin, the living should endeavour:

to live without our Bodies now, as much as possibly we can ... to have but very little commerce with flesh and sense; to wean our selves from all bodily pleasures, to stifle its appetites and inclinations, and to bring them under perfect command and government ${ }^{30}$

The body after death was an object lesson in vanity, futility and the inherent failure of the flesh. Another Protestant theologian, Zacharie Boyd, was in little doubt as to the ultimate value of the body: 
Is it not your greatest desire to flitte from this bodie which is but a Booth, a shoppe, or Tabernacle of clay? Is not your Soule wearied to sojourne into such a reekie lodge? ${ }^{31}$

The memento mori tradition of the late Middle Ages used the image of the dead body (as rotting cadaver or dry bones) to emphasise the transience of human life and the inevitable fate of the flesh (Fig. 3.2). In the early modern period the dead body continued to function as a moral lesson to the living, reminding them to prepare for their own death (all the more urgent now that the preparation of one's own soul during life was the only way to improve one's prospects of salvation afterwards), but it was also a material demonstration of futility and of the unworthiness of the body. The dead corpse was body without soul. Its ugliness and stink showed the baseness of earthly life and proved that all beauty in the body had come from the soul.

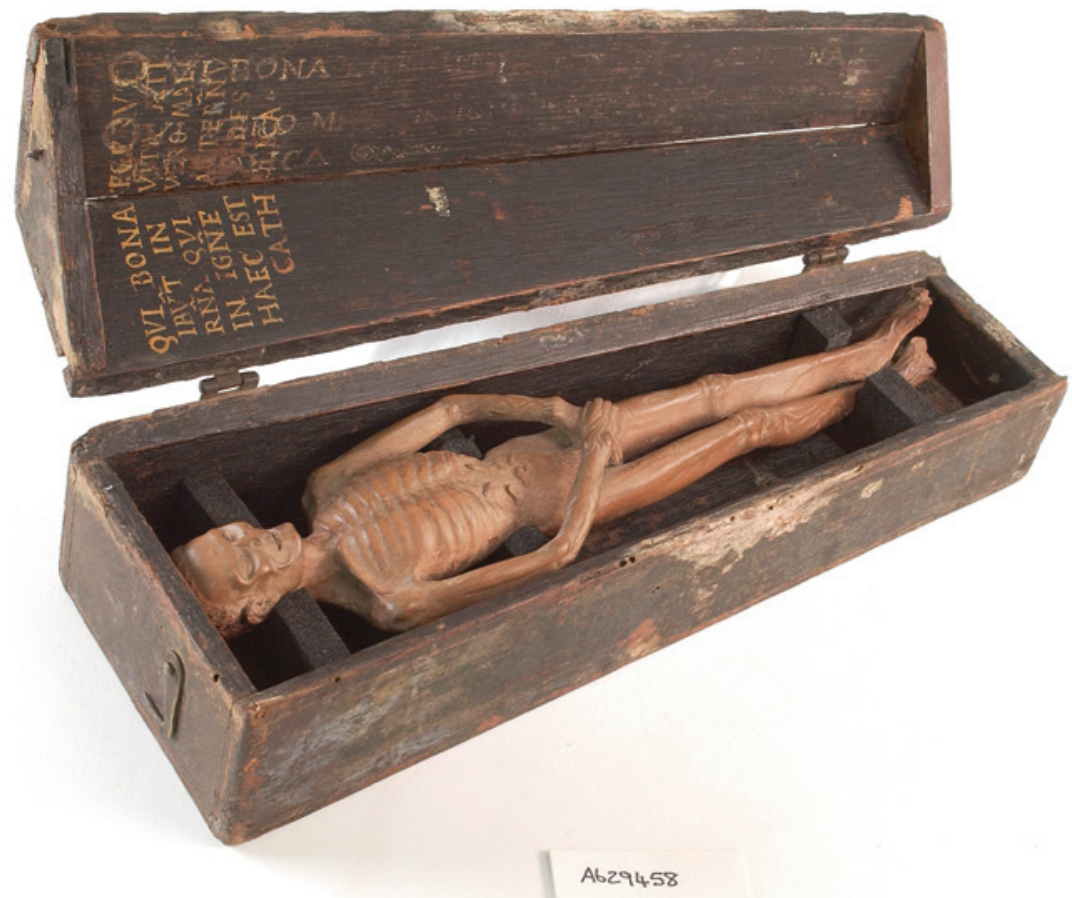

Fig. 3.2 Memento mori figure, a talisman to remind the holder of the transience of life and the vanity of earthly attachments (Wellcome Collection) 
In this moral and religious climate, the body of the executed criminal was already freighted with meaning. Sin-in the form of acting on the criminal lusts of the unconstrained body-had resulted in death, and what an ugly, abject, dishonourable thing that traitorous body turned out to be when the spark of divinity was removed.

For condemned criminals, as for all people, the moment of death took on even greater significance as the state of the soul was sealed at this point. The last few minutes or even seconds of life became more decisive of a person's fate. Even a very late repentance, if sincere, could save the worst of criminals. This added drama to an already highly symbolic moment: would the sinner be damned or could they yet save themselves?

Ideal deaths were described in ars moriendi (art of dying) books, a literary tradition that began in the fifteenth century and continued to flourish through the early modern period. ${ }^{32}$ The changing religious content of an ideal death, and the gradually shifting priorities of 'Moriens', the central character of the dying man, are a useful insight into how the Reformation and accompanying social changes impacted on what people aspired to achieve at the moment of leaving life. In a post-Reformation context, as in earlier periods, secular concerns such as writing a will and arranging for the payment of any outstanding debts, are dealt with quite quickly, and the real focus is on preparing the soul, through prayers of true contrition and repentance. Protestant ars moriendi, however, are distinguished from their predecessors by the absence of formalised ritual wording, and an additional emphasis on the hope of salvation and forgiveness, and the reduced role of friends and family, whose prayers no longer 'counted' for the dying, though they could still remind the person at the centre of the drama of their spiritual hopes and dangers.

Houlbrooke examines the profuse literature dealing with the good death that was published during the 150 years following the Reformation. ${ }^{33} \mathrm{He}$ points to some of the most popular ars moriendi books of the seventeenth to early eighteenth centuries, including John Hayward's The Horrors and Terrors of the Hour of Death, which had 21 editions between 1690 and 1730, and Hell's Everlasting Flames Avoided, published in 35 editions over a similar period. William Sherlock's $A$ Practical Discourse Concerning Death went through at least 46 editions from 1689. In some ways, argues Houlbrooke, the moment of death was less rather than more important. ${ }^{34}$ To a well-prepared soul in the Puritan tradition, the spiritual work necessary for salvation was accomplished during a virtuous and devout life; no particular death-bed performance was required. However, in the case of a bad life-which all 
condemned criminals had necessarily followed-a final moment of repentance could still be a redemptive act. Houlbrooke also notes, however, the power of a condemned criminal to subvert the expected rituals 'by a show of debonair indifference, or their drunken stupor at the gallows' ${ }^{35}$ Foreign observers, including Henri Misson, remarked on the fine appearance of those going to be hanged. ${ }^{36}$ It was customary in early modernity for them to be well-dressed and newly shaved for their final journey. Gemelli, an Italian visitor, noted in 1701 that the condemned approached the scaffold 'as if going to a wedding'. ${ }^{37}$ The comparison is apt. A popular belief was that a man could be saved from the noose if a woman agreed to marry him. ${ }^{38}$

In a survey of the popular murder literature of the early seventeenth century, Peter Lake identifies the tradition in pamphlets of crime and punishment that demanded a public confession and an expression of contrition before death. ${ }^{39}$ This was not only a religious imperative, but also a theatrical restoration of moral and social order. Like Houlbrooke, Lake finds that the condemned criminal could, and sometimes did, subvert the prescribed behaviour. When the prisoner went to the scaffold drunk or ostentatiously unrepentant, the execution could become a carnival, exploiting the popular conventions of inversion and misrule. Like other carnivals of misrule, 'the executions... and the popular festivities which accompanied them, were structured by precisely the same principles of inversion followed by the reaffirmation of social unity' ${ }^{40}$ But where the usurping carnival king would be deposed in order to restore order, the criminal Lord of Misrule was actually rather than symbolically slain.

Popular murder narratives closed down ambiguity and imposed a particular interpretation, sometimes using the familiar arc through inversion of the normal order to a restoration and reaffirmation to channel the narrative to its moral. ${ }^{41}$ The theatre of the scaffold, the gibbet and the anatomy room attempted the same kind of scriptwriting, using the actual body of the transgressor as both actor and prop.

As we shall see in the next section, attempts to tie down the criminal corpse to an unambiguous true story were not entirely successful. Counternarratives positioning the criminal as hero or martyr, for example, could be appropriated and subvert the orthodox account. Laqueur, writing about execution mostly in the eighteenth century, argues that the carnivalesque elements of execution, both intentional (the bravado of the 
central subject) and unplanned (ropes breaking, nooses failing, squabbles breaking out on the scaffold) meant that the State was never sure of being able to impose its lesson on its own terms. ${ }^{42} \mathrm{We}$ shall return to the disruptive potential of the polyvalent theatre of execution in later chapters.

Beattie says that in the seventeenth century there was a move away from capital punishment for serious crimes as the option of transportation became available. ${ }^{43}$ This is certainly compelling if capital punishment is considered mainly as a solution to the problem of what to do with convicted felons. But a hanging-or even more, a beheading or burning - was not only, and maybe not even primarily, an efficient way of processing a deviant body out of society. The many ceremonial and public aspects of early modern execution demonstrate that a hanging accomplished symbolic ends that a simple removal from normal life and decent company, as with transportation or incarceration, could not. It was important that justice should be seen to be done: retribution achieved, social revenge enacted, would-be enemies of society deterred. While in this period, transportation could often be a lethal sentence, a death abroad or at sea did not have the theatrical and demonstrative potential of a staged execution.

\section{Good and Bad Deaths}

Despite the reformed Church's emphasis on the importance of soul and the insignificance of body, the 'decent' treatment of the corpse remained a priority for most. Perpetuation of a secular 'afterlife' replaced the spiritual one for survivors. The appropriate and dignified disposal of the corpse was important to everyone, and was afforded to all but the worst offenders. In 1739 Richard Tobin, condemned to hang for theft, wrote to his former master, 'Take some pity on me... for my friends is very poor and my mother is very sick, and I'm to die next Wednesday morning, so I hope you will be so good as to give my friends a small trifle of money to pay for a coffin and a shroud, for to take my body away from the tree that I am to die on'. ${ }^{44}$ It is notable that by the early eighteenth century, a respectable burial, even for the very poorest in society, involved a shroud and coffin. Coffin use, a limited and elite practice for most of the Middle Ages, became by the eighteenth century part of the minimum requirement for decency. Laqueur notes that 
as the expectations of a decent funeral expanded, the lack of a full and proper one became more shameful. ${ }^{45}$ By the nineteenth century, a burial that smacked of poverty was as shameful, he claims, as one that signalled criminality.

Prisoners who died in gaol were normally returned to their family and their home parish for burial. Most executed offenders were buried, although this was commonly carried out in the graveyard of the parish where the gaol or the scaffold was located. ${ }^{46}$

In early modernity, then, post-execution defilement gained its potency from its comparative infrequency and because it was a denial of what was most important. As Gittings comments, 'this desire to punish the dead corpse... makes sense only against a background of a society in which the decent interment of the dead was a matter of the utmost concern' ${ }^{47}$

Honourable or dishonourable treatment of a dead body, even years after the death, not only reflected, but actively constructed a person as a respectable individual or a criminal. Two contrasting cases from early 1661 illustrate this. Following the restoration of the monarchy, the body of Oliver Cromwell, regicide, self-proclaimed Lord Protector and crypto-king, was disinterred from its resting place in Westminster Abbey, hanged at Tyburn and then beheaded. As was the case with others convicted of treason, Oliver Cromwell's head was placed on a spike and displayed to the public. This (delayed) post-mortem punishment stands in contrast to the ostentatious and hugely expensive state funeral he had been granted at the time of his death three years earlier. ${ }^{48} \mathrm{At}$ almost exactly the same time as Cromwell's body, along with those of fellow regicides Bradshaw and Ireton, was being dragged to Tyburn, the Marquis of Montrose underwent a similar reversal of fortune, though in his case the post-mortem transformation was from traitor to national hero. The Marquis had been executed in Edinburgh in 1650 when he had been fighting for Charles II against Cromwellian forces and dismembered. Eleven years later his remains were reassembled and brought together in a series of ceremonial processions involving velvet canopies and elaborate caskets for a lavish funeral, costing the enormous sum of $£ 802$ sterling, conducted at the king's expense. ${ }^{49}$ In both these cases, the body itself was manipulated, even years after death, to make a particular story: in Cromwell's case it was to transform the story of a great ruler into one of a traitor, and an aberration in the history of England; in Montrose's, a criminal and traitor was transformed into a hero and martyr. 


\section{Uses of THe CRIMINAL Body}

\section{The Power of the State}

One of the first major developments of early modern political history to be introduced to new students of the period is the formation of nation states. Some countries, including England, had already mostly coalesced during the Middle Ages (and others, such as Italy and Germany, took rather longer), and during this period larger, more unified and centralised political states took the forms that they held through modern history. As part of this process, the government of the state-whether monarchy or, increasingly, a more parliamentary institution-was at pains, in overt and subtle ways, to assert its authority. The consolidation of state control happened against a background of social reorganisation in the wake of Reformation, early English colonialism and the advent of sustained European transatlantic contact, and as an individualistic capitalism began to replace a totally local and cryptofeudal set of personal loyalties.

A key site in this renegotiation was the human body. The control and discipline of the living body was fundamental to running a modern State. An efficient army and a lively economy depended on work discipline, bodily knowledge, and rigid conformity with codes of physical behaviour, as has been extensively discussed by Michel Foucault and Norbert Elias, and before them by Max Weber. ${ }^{50}$ The disciplined body was essential also in the controlled exchange of labour, materials, and goods which made the protocapitalism of early modernity.

The ideal body for the nascent nation state, then, was a controlled, disciplined, productive one. A high degree of conformity to shared standards of behaviour was encouraged by the state and facilitated by adherence to a national religion. Failure to live up to the normative standards of behaviour appropriate to a person's age, status and gender resulted in sanctions. For minor social transgression, the local 'moral economy' drew on a repertoire of punishments that mostly worked through shaming the malefactor and almost invariably centred on the humiliation of the body. These included medieval hangovers like branding, punitive amputation, and public display, such as a period in the stocks, public whipping or one of the various local manifestations of charivari-riding the strang, rough music, skimmington, ceffyl pren-all of which involved some kind of humiliating procession through town, 
usually on a wooden horse, in a state of undress or foolish attire, while enduring the catcalls and assaults of the community. Sanctions like these helped to police sexual behaviour, gender roles, and moral or religious obedience. For more grave crimes including serious violence and murder, major property crime, and especially anything that might be considered treason, the state intervened to impose a punishment decreed by an increasingly centralised and formalised judiciary.

As in the medieval period, nearly all punishments were public and depended on the twin forces of pain and shame to act as deterrent, retribution, or memorable display. The early modern period was the golden age of spectacular punishment. The body of the convict had a starring role in this pageant of retribution. On it-alive and dead, whole and in pieces-were piled humiliations and horrors for the consumption of the crowd. These were brutal demonstrations of state power and the price for opposing it. Linebaugh uses the word 'thanatocracy' (in much of his published work) to mean a government that rules by deploying the death penalty. ${ }^{1} \mathrm{He}$ interprets public hanging as a tool in the shaping and control of the working classes during the rise of capitalism. ${ }^{52}$ But some criminals chose to go defiantly to their ends.

\section{Subverting the Theatre of Pain}

Even at its most authoritarian and repressive, the state always ran the risk that key performers in the spectacle of pain would go off-script and undermine the whole show. Because the criminal about to be executed was, first, likely by definition to be the kind of person willing to ignore or rework social norms and, second, given a person with little or nothing to lose at this point, the performance could go dangerously awry. The crowd had to be sensitive to the agony of the criminal, but if they identified with them too closely, or found the malefactor too charming or sympathetic, then they felt antagonism towards the state rather than awe. If the prisoner was amusing or drunk, or things went wrong with the actual execution, the solemnity of the occasion could be undermined by comedy. The ambiguity of the criminal facing death that was outlined in Chapter 2 persisted into this period. The line between felon and martyr; traitor and hero; murderer and saint could easily collapse if the protagonist refused to play the proper part. Ideally, condemned convicts met their fate with penitence and regret, acknowledging the justice of the sentence, as they acknowledged the ultimate power of the state as the 
guardian of orderly society. Such a role was salutary to the crowd, and the moral order of the nation was restored in the ceremonial payment of a blood price. In order to achieve the ideal death, one in which 'blood might be recompensed with blood and the land may be cleansed from the guilt thereof', the criminal should make a public confession and an expression of remorse. ${ }^{53}$ Ministers were brought in to coach and prompt the principal actor, and executions were occasionally delayed if it seemed likely that a little more time would yield the desired result. ${ }^{54}$

The hope of an eleventh-hour pardon was reason enough for many criminals to work for a delay in execution. Laqueur notes that the frequent expectation of a last-minute reprieve produced a 'comedy of pardons' in the seventeenth century, where uncertainty about the outcome of a planned execution detracted from the dignity of the occasion. ${ }^{55}$ For Laqueur the numerous contingencies of the execution event prohibit any reductive interpretation of the complex scene as 'coherent state theatre' in a Foucauldian sense. ${ }^{56}$

Laqueur's reservations are not uniquely retrospective. By the eighteenth century, literate commentators were expressing similar sentiments. For Samuel Richardson all the faces in the Tyburn crowd showed 'a kind of mirth', the thrill of pleasure at a public theatrical entertainment rather than fear and awe to see the might of the state in action. ${ }^{57}$ Fellow novelist Henry Fielding set out a detailed account of his objection to public punishment. ${ }^{58}$ For Fielding it was not the comedic element that tended to undermine the moral lesson, but the pathetic ones. The drama of the execution failed in its intent because the audience felt sympathy with the criminal as they faced the pitiless machine of justice. The perpetrator of violence became its victim. In other scenarios, repugnance for the grislier elements of physical or capital punishment undermined rather than reinforced the legitimacy of the state.

The punishment for treason remained the same as in the medieval period, and its elements equally symbolic. John Owen's sentence for treason in 1615 included first, that he be drawn to the place of execution 'as he is not fit to walk upon the earth: 2 . His privy members cut off ... which shows that his issue is disinherited with the corruption of blood... 3. His bowels burned because in them he hatched the treason: 4. Beheaded: 5. Dismembered'. ${ }^{59}$ The extremely somatic nature of both crime and punishment is very explicit here. But how far was a symbolic glossing of the components of punishment necessary or available for the attending crowd to interpret the event properly? 
Even after death, the body of a traitor could be co-opted into new and subversive narratives. The family of William Stayley, a Catholic executed in 1678 for high treason, asked for the return of his body for burial. Because of his penitent behaviour before death, Charles II granted their request. However, instead of conducting a funeral of the decent but humble type consistent with Stayley's role as a repentant criminal, his family chose to bury him in the lavish and ostentatious fashion of a hero and martyr. The king was not prepared to lose control of the narrative. He ordered the body to be disinterred, and Stayley's quarters to be set up above the gates of London as originally planned. ${ }^{60}$

In the cases of other Catholic martyrs (and the events of the sixteenth and seventeenth centuries meant that there were dozens of them in the early modern period), body parts removed as part of a punishment that worked through humiliation and the denial of a decent burial were reappropriated and redefined as holy relics. The hand of St Margaret Clitheroe, executed in 1586 is still preserved and venerated at the convent of the Blessed Virgin in York; and that of St Edmund Arrowsmith, executed in 1628 is at St Oswald's church, Ashton in Makerfield. The body of another Catholic saint, St Oliver Plunkett, who was executed for treason in 1681 was rescued from the pyre after death, divided and preserved as holy relics in several locations around Europe ${ }^{61}$ Most famously, his head, once held up as that of a traitor, is now the most important relic at St Peter's Cathedral, Drogheda. His head has participated not only in religious narratives of faith and martyrdom, but also nationalist ones of oppression and resistance.

The creation of a martyr-either an actual religious martyr or a social and cultural one-involved not only material relics, but also the invention and propagation of stories. The cultural afterlives of criminal bodies will be discussed further in Chapter 8 .

\section{Early Modern Criminal Bodies}

Archaeologists in general derive a great deal of their evidence about the past from the remains of the dead. Bones and graves, after all, leave material traces that frequently survive and that can be interrogated to yield information about past practices, including diet, social organisation, cultural affiliation, social identities of gender, age and status, disease, consumption and economics, among other things. 
Accordingly, a commonplace has arisen that when we study the dead we are actually studying the living. The dead, goes the archaeological wisdom, do not bury themselves. There has thus been an assumption in much archaeological work that the bodies of the dead are passive and manipulable symbols through which the living pursue their own strategies of representation that promote the social or economic interests of their own kind. A study of the criminal corpse in early modernity exposes problems with that perspective. First, such a view takes no account of the emotional impact of death, especially a stigmatised, traumatic and early death such as execution. For the executed person, for their kin and for the wider community of witnesses, execution was a terrible fate, and could inspire fear, anger, sympathy, grief, disgust, awe, contrition, spiritual reflection, revolution or any combination of feelings. Second, the dead criminal body was an unreliable symbol that was not easily co-opted into the meaningful narrative composed by any group or individual. Instead it was polyvalent and ambiguous. The living may bury the dead, but the dead resist the stories we impose upon them.

\section{The Criminal Body in Different Belief Discourses}

At the outset of the project on which this book is based some colleagues were concerned that executed criminal bodies were too few in number and too marginal to the experience of most people in the past to make a sufficiently fruitful focus for a large interdisciplinary endeavour. In fact, not only have our findings exceeded our expectations, the interdisciplinarity of our work has allowed some new things to emerge that would never have arisen if we had followed separate traditional disciplinary paths. One of these is the issue of how different belief discourses relate to one another. The criminal body had a prominent presence in popular culture as well as science, civic life and medico-legal activity. It is historically significant as the site of overlapping and sometimes contradictory understandings between scientific anatomy, criminal justice, popular medicine and social geography. However, because those areas are traditionally only examined within a single disciplinary tradition (history of medicine, art history, folklore, literature, etc.), contradictions and incompatibilities between different forms of understanding the criminal body do not necessarily present themselves. Our way of working has demanded that we address incommensurable beliefs and the significance of context. 
- We take as our starting point the idea that the criminal corpse, even when life had left the body, was still a powerful object. It had social and symbolic power, which was manipulated by the State and other interest groups, as well as medicinal and curative power.

- It was a key source for the creation and deployment of the power of scientific and medical knowledge, and of discretionary judicial power. In some cases, it was also understood to have its own agentive power.

- The power of the criminal corpse was harnessed in the promotion of particular social interests (in relation to class, gender and race for example). It was used instrumentally in the construction of knowledge and in medicine.

- Beliefs about, and the idea of, the criminal corpse informed popular culture and the development of historically situated normative ethics which continue to affect our beliefs about the dead body today.

- Culturally the criminal body is located at the overlap of several different traditions of discourse and practice and is a lens through which tensions such as normal/abnormal, and ethical/unethical can be explored in historical context.

In the overlap between modes of knowledge about the criminal body we find not only shared concerns and 'leakage' of assumptions and values from one area to another, but also contradictions and incommensurabilities which challenge us to develop more sophisticated understandings about how knowledge, belief, practice and resistance were produced and reproduced in the past.

Part 1 of this book has set out its aims, and outlined the historical lineage of the post-mortem punishments of the Murder Act. Part 2 focuses our examination of the criminal corpse during that period and looks in more detail at the tensions between retribution and humanity, deterrence and justice, science and prurience that characterise it.

\section{Notes}

1. See, Dyer, C. (2005), An Age of Transition? Economy and Society in England in the Later Middles Ages (Oxford: Clarendon Press).

2. Russell, K.F. (1987), British Anatomy 1525-1800: A Bibliography of Works Published in Britain, America and on the Continent (London: St Pauls Biographies), p. xviii. 
3. Ibid., p. xxi.

4. See, Park, K. (1995), 'The Life of the Corpse: Division and Dissection in Late Medieval Europe', Journal of the History of Medicine and Allied Sciences, Vol. 50, Issue 1, 111-132.

5. Ibid., p. 119.

6. See, Sawday, J. (1995), The Body Emblazoned: Dissection and the Human Body in Renaissance Culture (Abingdon: Routledge), p. 55.

7. See, Poole, S. (2015), "For the Benefit of Example": Crime-Scene Executions in England, 1720-1830', in Ward, R. (ed.), A Global History of Execution and the Criminal Corpse (Basingstoke: Palgrave), pp. 71-101.

8. See, Davies, O. and Matteoni, F. (2016), Executing Magic: The Power of Criminal Bodies (Basingstoke: Palgrave).

9. See, Harland, J. and Wilkinson, T. (1882), Lancashire Folk-Lore (Manchester: John Heywood), p. 128; Weever, J. (1631), Ancient and Funerall Monuments with in the United Monarchie of Great Britaine, Ireland and the Islands Adjacent (London: Thomas Harper), p. 45.

10. See, Foucault (1978), A History of Sexuality, Vol I: The Will to Knowledge (Harmondsworth: Penguin).

11. See, Harris, O.J.T., Robb, J., and Tarlow, S. (2013), 'The Body in the Age of Knowledge', in Robb, J. and Harris, O.J.T. (eds.), The Body in History (Cambridge: Cambridge University Press), pp. 164-195, quote on p. 172.

12. See, Lewis, C.S. (1964), The Discarded Image (Cambridge: Cambridge University Press), p. 148.

13. See, Werness, H.C. (2006), Continuum Encyclopedia of Animal Symbolism in World Art (New York: Continuum), p. 37.

14. See, Aziz et al. (2002), 'The Human Cadaver in the Age of Biomedical Informatics', Anatomical Record, Vol. 269, Issue 1, 20-32.

15. See, Ghosh, S.K. (2015), 'Human Cadaveric Dissection: A Historical Account from Ancient Greece to the Modern Era', Anatomy and Cell Biology, Vol. 48, Issue 3, 153-169.

16. Siraisi, N.G. (1990). Medieval and Early Renaissance Medicine: An Introduction to Knowledge and Practice (Chicago: University of Chicago Press).

17. See, Sawday, J. (1995), The Body Emblazoned: Dissection and the Human Body in Renaissance Culture (Abingdon: Routledge).

18. See for example, Thomas, J. (2004), Archaeology and Modernity (London: Routledge).

19. See, Sawday, J. (1995), The Body Emblazoned: Dissection and the Human Body in Renaissance Culture (Abingdon: Routledge).

20. See, Nixon, A. (1612), The Dignity of Man, Both in the Perfections of His Soule and Bodie, p. 8. 
21. See, Tarlow, S. (2010), Ritual, Belief and the Dead in Early Modern Britain and Ireland (Cambridge: Cambridge University Press).

22. See, Hillman, D. and Mazzio, C. eds. (1997), The Body in Parts. Fantasies of Corporeality in Early Modern Europe (London: Routledge), quote at p. xi.

23. The British Library catalogue lists in the half century before 1625 , among others, The Anatomie of the Mind (Thomas Rogers 1576), The Anatomie of Wit (John Lyly 1579), The Anatomie of Abuse (Philip Stubbes 1583), The Anatomie of Fortune (Robert Greene 1584), The Anatomie of Absurdity (Thomas Nash 1590), The Anatomie of Popish Tyrannie (Thomas Bell 1603), The Anatomie of Sorcery (James Mason 1612), The Anatomie of Mortality (Strode 1618), Follie's Anatomie (Henry Hutton 1619), The Anatomie of Vanitie (Richard Brathwait 1621), The Anatomie of Conscience (Immanuel Bourne 1623), The Anatomie of Protestancie (O.A. 1623) and The Anatomie of the Roman Clergy (George Lauder 1623). See, Tarlow, S. (2010), Ritual, Belief and the Dead in Early Modern Britain and Ireland (Cambridge: Cambridge University Press).

24. See, Tarlow, S. (2013), 'Cromwell and Plunkett: Two Early Modern Heads Called Oliver', in Kelly, J. and Lyones, M. (eds.), Death and Dying in Ireland, Britain and Europe: Historical Perspectives (Dublin: Irish Academic Press), pp. 59-76.

25. The origins of the use of a stylised Guy Fawkes mask in late twentieth-century protest derive from the graphic novel $V$ for Vendetta (1989) written by Alan Moore and illustrated by David Lloyd, which formed the basis for the 2005 blockbuster film by the same name, directed by James McTeigue and written by The Wachowskis. On the use of Guy Fawkes imagery in anti-government protest, see Call, L. (2008), 'A Is for Anarchy, V. Is for Vendetta: Images of Guy Fawkes and the Creation of Postmodern Anarchism', Anarchist Studies, Vol. 16, Issue 2, 154-172.

26. See for example, Weber, M. (1904-1905/1970), The Protestant Ethic and the Spirit of Capitalism (London: Allen \& Unwin, 1970 edition); Tawney, R.H. (1926), Religion and the Rise of Capitalism (London).

27. See, Ariès, P. (1981), The Hour of Our Death (Harmondsworth: Peregrine), quote at p. 298.

28. See, Gordon, A. and Rist, T. eds. (2013), The Arts of Remembrance in Early Modern England: Memorial Cultures of the Post Reformation (Farnham: Ashgate).

29. See, Brown, T. (1979), The Fate of the Dead: A Study in Folk-Eschatology in the West Country After the Reformation (Cambridge: D.S. Brewer), quote at p. 16.

30. See, Sherlock, W. (1690), A Practical Discourse Concerning Death (London: W. Rogers, 2nd edition), quote at p. 53. 
31. See, Boyd, Z. (1629), The Last Battell of the Soule in Death (Edinburgh: Heires of Andro Hart), quote at p. 84.

32. See, Owen, K. (2000), Identity, Commemoration and the Art of Dying Well: Exploring the Relationship Between the Ars Moriendi Tradition and the Material Culture of Death in Gloucestershire, c.1350-1700A.D. (Oxford: British Archaeological Reports).

33. See, Houlbrooke R. (1999), 'The Age of Decency: 1660-1760', in Jupp, P.C. and Gittings, C. (eds.), Death in England: An Illustrated History (Manchester: Manchester University Press), pp. 174-201.

34. Ibid., p. 183.

35. Ibid., quote at pp. 184-185.

36. Henri Misson M., Misson's Memoirs and Observations in His Travels over England, with Some Account of Scotland and Ireland. Written Originally in French and Translated by Mr Ozell (London, 1719).

37. As cited in, Gittings, C. (1984), Death, Burial and the Individual in Early Modern England (London: Routledge), p. 64.

38. William Andrews in Old Church Lore (William Andrews \& Co., The Hull Press; London, 1891; pp. 191-194) cites a number of ballads that make a joke of the condemned man choosing execution over marriage. Oloudah Equiano, in his Interesting narrative, reports witnessing a man saved from death in this way in New York in 1784: 'One day a malefactor was to be executed on a gallows; but with a condition that if any woman, having nothing on but her shift, married the man under the gallows, his life was to be saved. This extraordinary privilege was claimed; a woman presented herself; and the marriage ceremony was performed'.

39. See, Lake, P. (1993), 'Deeds Against Nature: Cheap Print, Protestantism and Murder in Early Seventeenth-Century England' in Sharpe, K. and Lake, P. (eds.), Culture and Politics in Early Stuart England (Stanford: Stanford University Press), pp. 257-284, esp. p. 274.

40. Ibid., quote at p. 276.

41. Ibid., p. 276.

42. See, Laqueur, T.W. (1989), 'Crowds, Carnival and the State in English Executions, 1604-1868', in Beier, A.L., Cannadine, D., and Rosenheim, J.M. (eds.), The First Modern Society: Essays in English History in Honour of Lawrence Stone (Cambridge: Cambridge University Press), pp. 305-355.

43. See, Beattie, J.M. (1986), Crime and the Courts in England 1660-1800 (Oxford: Oxford University Press).

44. Quoted in, Linebaugh, P. (1975), 'The Tyburn Riot Against the Surgeons', in Hay, D., Linebaugh, P., Rule, J.G., Thompson, E.P., and Winslow, C. (eds.), Albion's Fatal Tree (New York: Pantheon Books), pp. 65-118, at p. 83.

45. See, Laqueur, T.W. (2015), A Cultural History of Mortal Remains (Woodstock: Princeton University Press), p. 316. 
46. See, Gittings, C. (1984), Death, Burial and the Individual in Early Modern England (London: Routledge), p. 67.

47. Ibid., quote at p. 71.

48. See for example, Kilfeather, S. (2002), 'Oliver Plunkett's Head', Textual Practice, Vol. 16, Issue 2, 229-248 and Tarlow, S. (2008), 'The Extraordinary Story of Oliver Cromwell's Head', in Robb, J. and Borić, D. (eds.), Past Bodies: Body-Centred Research in Archaeology (Oxford: Oxbow Books), pp. 69-78; Tarlow, S. (2013), 'Cromwell and Plunkett: Two Early Modern Heads Called Oliver', in Kelly, J. and Lyones, M. (eds.), Death and Dying in Ireland, Britain and Europe: Historical Perspectives (Dublin: Irish Academic Press), pp. 59-76.

49. See, Bennett, R. (2017), “A Candidate for Immortality”: Martrydom, Memory, and the Marquis of Montrose', in McCorristine, S. (ed.), When Is Death? Interdisciplinary Perspectives on Death and Its Timing (Palgrave Macmillan).

50. For example, Foucault, M. Discipline and Punish (Pantheon 1977), The History of Sexuality (1978, 1985, 1986). See, Elias, N. (1939/2000), The Civilising Process, trans. Edmund Jephcott (Oxford: Blackwell, revised edition); Weber, M. (1904-05/1970), The Protestant Ethic and the Spirit of Capitalism (London, Allen \& Unwin, 1970 edition).

51. See for example, Linebaugh, P. (1991), The London Hanged: Crime and Civil Society in the Eighteenth Century (London: Verso), p. 42.

52. See, Bailey, V. (2000), 'The Death Penalty in British History', Punishment and Society, Vol. 2, Issue 1, 106-113.

53. See, Lake, P. (1993), 'Deeds Against Nature: Cheap Print, Protestantism and Murder in Early Seventeenth-Century England', in Sharpe, K. and Lake, P. (eds.), Culture and Politics in Early Stuart England (Stanford: Stanford University Press), pp. 257-284, quote at p. 274.

54. Ibid., p. 274.

55. See, Laqueur, T.W. (1989), 'Crowds, Carnival and the State in English Executions, 1604-1868', in Beier, A. L., Cannadine, D., and Rosenheim, J.M. (eds.), The First Modern Society: Essays in English History in Honour of Lawrence Stone (Cambridge: Cambridge University Press), pp. 305-355, quote at p. 327.

56. Ibid., p. 322.

57. See, Richardson, S. (1928), Familiar Letters on Important Occasions (London: Routledge, lst edition, 1741), pp. 217-219.

58. Described in, Laqueur, T.W. (1989), 'Crowds, Carnival and the State in English Executions, 1604-1868', in Beier, A.L., Cannadine, D., and Rosenheim, J.M. (eds.), The First Modern Society: Essays in English History in Honour of Lawrence Stone (Cambridge: Cambridge University Press), pp. 305-355. 
59. See, Howell, T.B. (1816), A Complete Collection of State Trials, Vol. II, Coll. 84 (London: Longman).

60. See, Gittings, C. (1984), Death, Burial and the Individual in Early Modern England (London: Routledge), pp. 70-71.

61. Discussed in, Kilfeather, S. (2002), 'Oliver Plunkett's head', Textual Practice, Vol. 16, Issue 2, 229-248; Tarlow, S. (2013), 'Cromwell and Plunkett: Two Early Modern Heads Called Oliver', in Kelly, J. and Lyones, M. (eds.), Death and Dying in Ireland, Britain and Europe: Historical Perspectives (Dublin: Irish Academic Press), pp. 59-76.

Open Access This chapter is licensed under the terms of the Creative Commons Attribution 4.0 International License (http://creativecommons.org/licenses/ by $/ 4.0 /$ ), which permits use, sharing, adaptation, distribution and reproduction in any medium or format, as long as you give appropriate credit to the original author(s) and the source, provide a link to the Creative Commons license and indicate if changes were made.

The images or other third party material in this chapter are included in the chapter's Creative Commons license, unless indicated otherwise in a credit line to the material. If material is not included in the chapter's Creative Commons license and your intended use is not permitted by statutory regulation or exceeds the permitted use, you will need to obtain permission directly from the copyright holder.

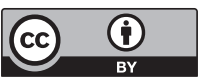

